\title{
Revegetation of steeplands in France and New Zealand: geomorphic and policy responses
}

\author{
Chris J Phillips ${ }^{1 *}$, Freddy Rey ${ }^{2}$, Michael Marden ${ }^{3}$ and Frederic Liébault ${ }^{2}$
}

\begin{abstract}
Background: Efforts to address erosion and land degradation in steeplands of many countries have largely relied on revegetation. The policy responses to this issue are many and varied as have been their successes. Revegetation efforts tend to occur when it is realised that deforestation, mountain land erosion, and flooding of rivers are linked.

Methods: Using the Southern Prealps region in France and the East Coast North Island region of New Zealand as 'study sites', past and current revegetation efforts to address steepland degradation were compared.

Results: Both areas have similarities in geology, geomorphology and types of erosion processes (shallow landsliding and gullying). Landscape responses to large-scale erosion and subsequent reforestation have been similar between France and New Zealand though major reforestation occurred in France more than a century before that in New Zealand. Attempts to control sediment production in headwater regions reinforces the view that conditions controlling the evolution of channel response (through time and space) to a change in sediment supply are complex. While there is a consistent sequence of responses in channels and on hillslopes to reforestation efforts and the direction of changes may be anticipated, the magnitude and timing of those responses are not.

Conclusion: The key lesson for future management and policy development arising from these studies is that erosioncontrol efforts that are aimed at producing basin-scale impacts will require targeting of areas where the proposed land use change or intervention will have the most beneficial influence on reducing sediment supply to river channels.
\end{abstract}

Keywords: Bioengineering; Deforestation; Erosion; East Coast; France; Flooding; Reforestation; Sediment yield

\section{Background}

Efforts to address erosion and land degradation in steeplands have largely relied on revegetation - reforestation (of former forests) or afforestation (of other land) - and rehabilitation or ground bioengineering (i.e. use of plant materials for soil protection and slope stabilisation with or without mechanical methods; Schiechtl and Stern, 1996). Countries that have experienced deforestation, subsequent erosion and then reforestation occur in many parts of the world (e.g. European Alps, Japan, United States, New Zealand, and France) and the process has been well documented (Kittredge, 1948; McKelvey, 1992; Mather et al., 1999). A large range of vegetation types and species have been used to control different erosion processes. Land use change, in the form of different vegetation cover, therefore, is often employed as a catchment-scale tool for

\footnotetext{
* Correspondence: phillipsc@landcareresearch.co.nz

'Landcare Research, PO Box 40, Lincoln 7640, New Zealand

Full list of author information is available at the end of the article
}

sediment management through planned modifications to that cover (Liebault et al. 2005).

The policy responses to this land degradation issue are many and varied as have been their successes. In France, for example, there is a long history of local, regional, and national revegetation efforts to deal with land degradation in steeplands. Human-induced deforestation in France dates from the Bronze Age, at $3500 \mathrm{BP}$, where palynology reveals a major decrease of the southern alpine forest cover (de Beaulieu, 1977). More recent periods of active deforestation occurred in the 17th and the early 19th centuries, and coincided with major peaks of population growth in the southern Alps (Blanchard, 1945). Revegetation efforts began in earnest in the 1860s when it was realised that deforestation, mountain land erosion, and flooding of rivers were linked (Dugied, 1819; Surell, 1841).

In contrast, efforts in New Zealand have been historically more recent. New Zealand has a young colonial history being first settled by Europeans in the 1800s, from which

\section{Springer}


time indigenous forest clearance continued into the early 20th century. The linkages between deforestation and downstream flooding were not made until well into the mid-20th century (e.g. Kennedy, 1912; Laing-Meason, 1914; Cumberland, 1947; O'Loughlin and Owens, 1987; McKelvey, 1992) at which time publicly funded conservation/ reforestation schemes were introduced.

In this paper, two areas of similar geology, geomorphology and types of erosion processes (shallow landsliding and gullying) - the Southern Prealps region in France and the East Coast North Island region of New Zealand were used to compare past and current revegetation efforts to address steepland degradation. An earlier assessment in which human-induced modifications of vegetation cover were assessed in terms of their geomorphic responses is built upon (Liebault et al. 2005; Cohen and Rey, 2005). The interventionist policies and resultant landscape responses between the two countries are compared, lessons learnt highlighted, and the implications for future policy development discussed.

\section{Methods \\ Study areas \\ Southern Prealps Region of France}

The Southern French Prealps are low-elevation (maximum height rarely exceeds $2000 \mathrm{~m}$ ) mountains primarily underlain by Jurassic and Cretaceous sedimentary rocks folded during the alpine orogenesis (Figure 1). Alternative sequences of marls and limestones are the dominant geology. Bedrock is often covered by surficial deposits from the Quaternary period (e.g. talus slopes). During the Würm period (2.6 million years to 11,700 years $\mathrm{BP}$ ), the region was only marginally occupied by glaciers and slopes were covered by periglacial deposits. Jurassic black marls are known to be the most erosive rocks in the Southern Prealps, with erosion rates of ca. 1 $\mathrm{cm} \mathrm{yr}^{-1}$ (Mathys et al., 2003). These muddy rocks are highly dissected by gullying, giving a typical badlands morphology. The surrounding landscapes include broad incised valleys and plateaux with steep escarpments.

The region is characterised by a mountainous climate with Mediterranean influences. Rainy periods occur during spring and autumn. Mean annual rainfall is between 850 and $1000 \mathrm{~mm}$. Extreme rainfall events generally occur during autumn and can reach values as high as $100-250 \mathrm{~mm}$ in $24 \mathrm{~h}$. Small upland catchments are sensitive to short-duration and high-intensity convective storms, which are known to trigger catastrophic flash floods and debris-flows during spring and summer.

Archaeological research indicates that the vegetation cover of the Southern Prealps has been impacted since the first permanent human settlements of the Neolithic period (c. 12,000 BP). In the Drôme River basin, an acceleration of the sedimentation rate on the alluvial fan at the confluence with the Rhône is observed during the Neolithic, a period during which grazing is present in the catchment (Brochier et al., 1991). Deforestation by agriculture has been active for thousands of years in this region, and the story of land use changes is difficult to reconstruct.

Historical accounts provide evidence of the dramatic human-induced hillslope erosion that took place between the 15th and 19th centuries (Blanchard, 1945). Periods of population pressure were associated with vegetation removal on hillslopes due to itinerant slashand-burn agriculture (Blanchard, 1945). Ash provided nutrients to the soil, and the deforested lands were cultivated for 2 or 3 years for the production of cereals, and then allowed to revert by encroaching vegetation. This practice became progressively abandoned in the second half of the 19th century, as rural population declined. Overgrazing by sheep and goats may have also been a factor in some areas, but its effect was much less important than that of slash-and-burn agriculture.

Deforestation of steep slopes induced dramatic geomorphic responses, as seen in many old photographs from the late 19th century (e.g. Figure 2). The increasing frequency of erosion processes on hillslopes supplied high sediment loads to small torrents which started to aggrade and widen their channels. Historical studies implemented in a small upland tributary catchment of the Drôme River revealed the succession of aggrading and degrading periods of the channel during the 19th century, with one dramatic aggradation phase initiated in 1856 under the effect of extreme summer convective storms, and that lasted until the early 20th century (Bravard, 2000).

Slopes were particularly affected by intense gullying, notably on muddy terrains. Sediment transport in small headwaters increased, and sediment waves travelled downstream to the large piedmont rivers. During the 19th century, most of the rivers draining this region were aggrading braided rivers with a high sediment load sourced from hillslope erosion (Bravard and Peiry, 1993). Local populations were exposed to an increased flooding risk in valley floors, subsequent to the aggradation of river channels. Small villages and agricultural lands established on alluvial fans were frequently inundated by debris-flows.

A recent study of the sedimentation in a palaeo-lake located in the Upper Drôme catchment revealed an erosion rate of $1850 \mathrm{t} \mathrm{km}^{2} \mathrm{yr}^{-1}$ between 1442 and 1795 for a drainage basin of $187 \mathrm{~km}^{2}$ (Buoncristiani et al., 2002). This value is one to two orders of magnitude higher than present-day erosion rates derived from alpine lakes with comparable drainage basins in the French Alps. This can be linked to the post-Little Ice Age warming, but also to the considerable land use changes that occurred in the Alps during the last 150 years. Today, although erosion is still active locally, a dense forest cover 


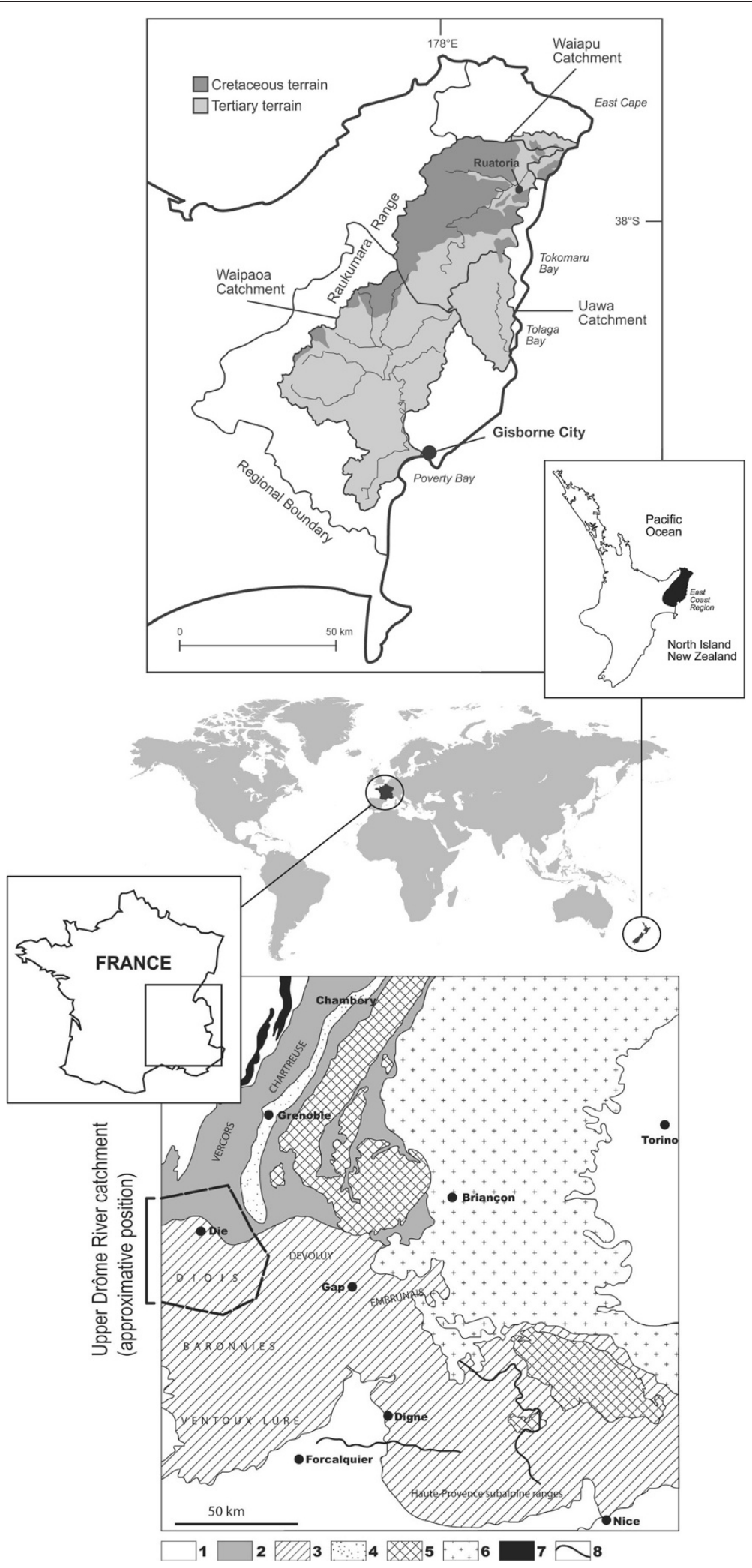

Figure 1 Location of the two study areas. On the bottom, the Southern French Prealps showing the alpine geological context: (1) perialpine molasse basins, (2) Northern Prealps, (3) Southern Prealps, (4) subalpine depression, (5) external crystalline Alps, (6) inner Alps, (7) Jura mountains, (8) thrust nappes (modified after Debelmas, 1983). On the top, the East Coast Region, North Island, New Zealand, showing the extent of the Cretaceous and Tertiary terrains within the Waipaoa, Waiapu and Uawa catchments (from Marden et al., 2008). 

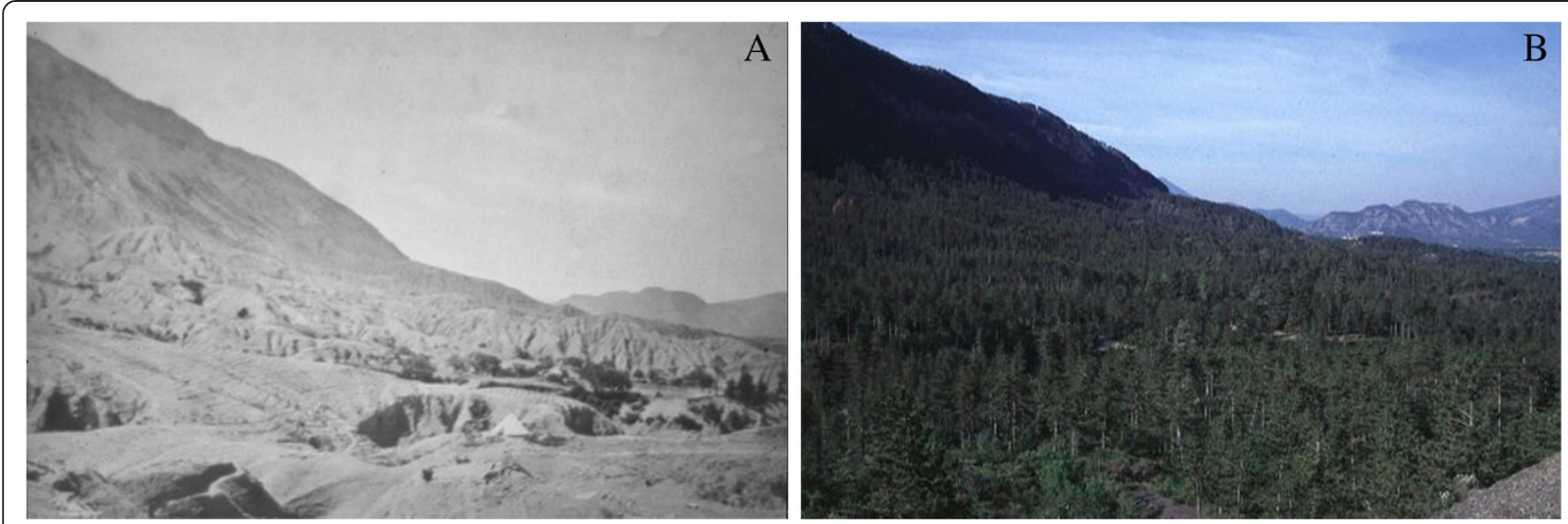

Figure 2 The Brusquet basin showing extensive erosion in 1887 (A) and in a revegetated state in 2007 (B) (source: Poirel, 2009).

has now established on the slopes as a result of reforestation and associated bioengineering works (Demontzey, 1880) and rural depopulation (Piégay et al., 2004; Liébault et al., 2005). Subsequently, some aggraded braided rivers have progressively incised to a singlethread channel, with moderate sediment loads (Liébault and Piégay, 2002).

In summary, the Southern Prealps illustrates the sensitivity of the upland environment to land use changes that occurred during the last 150 years. This is the result of the cumulative effects of steep slopes, presence of sensitive rocks to erosion, and a climate characterised by frequent extreme events.

\section{East Coast North Island Region of New Zealand}

The geology of the East Coast region (Figure 1) comprises mainly mudstones, sandstones and argillites, in a region that is characterised by moderately steep terrain (slopes greater than about $30^{\circ}$ ). In detail the geology is complex (Gage and Black, 1979; Mazengarb and Speden 2000) and uplift rates of about 3-4 $\mathrm{mm} \mathrm{yr}^{-1}$ are occurring (Wilson et al., 2007). Broadly, older rocks of Cretaceous age (fractured argillites, greywackes, and basalts) are dominant in the northern and western areas, while younger rocks of Tertiary age (soft mudstones, sandy mudstones, sandstones, and limestones) are dominant to the south and east. In the past 2000-60 000 years BP, the area has been covered with volcanic ash. While much has subsequently been eroded from unstable and/ or steep slopes, an ash cover remains intact on more gentle stable slopes and caps alluvial terraces. On steepland where the underlying rocks are moderately strong and stable, erosion is largely confined to the soil and regolith and occurs as sheet and rill erosion or as shallow landslides. However, where the underlying rocks are unstable, accelerated erosion involves the basal rock itself, producing deeply eroding gullies and accompanying earth slides and rotational slumps.
The annual rainfall for the region varies from about $1000 \mathrm{~mm}$ near the coast to over $2500 \mathrm{~mm}$ in higher inland country. More importantly, the region is also susceptible to severe storm events and occasionally to cyclones, which contribute to the incidence of erosion (e.g. Marden and Rowan, 1993). Although such storms are infrequent, they result in extreme flooding and many are associated with regional or widespread landsliding (Glade, 1998). For the Waipaoa River catchment (Figure 1) it is probable that a major flood-producing storm and associated extensive hillslope landsliding will occur once every decade (Kelliher et al., 1995). One major regional landsliding storm was in March 1988 (Cyclone Bola) in which $300-900 \mathrm{~mm}$ of rain fell in a 5-day period. Large storms and/or prolonged periods of rainfall that result in local to sub-regional landsliding are relatively more frequent (e.g. Gisborne District Council, 2012). There is a 29 per cent chance of a major event occurring every year in the Waipaoa catchment (Kelliher et al., 1995) but in the Uawa and Waiapu catchments to the north, erosion-generating storms and associated flooding have a recurrence interval between 2.6 years in the headwaters and 3.6 years near the coast (Hicks, 1995).

Concerns about the region's erosion problem have been long-standing. Various documents, commentaries, reviews and reports have discussed the nature of the problem and developed solutions to tackle it (Table 1). Some evidence suggests that the problems began during the early occupation by the indigenous people of New Zealand (Māori) (Wellman, 1962; Wilmshurst, 1997). The rate of erosion was, however, multiplied many times with the arrival of European settlers and their farming practices (1860s onwards) (Hill, 1895; Henderson and Ongley, 1920). Clearance of the indigenous forest by European settlers for pastoral production began in the 1880 s and by the 1920 s all but the highest and most rugged hill country had been cleared. Though some forested areas were logged, most were burnt then oversown with 
Table 1 Chronology of events leading to current reforestation scheme (East Coast Forestry Project) (modified from Phillips and Marden, 2005)

\begin{tabular}{|c|c|c|}
\hline Date & Action & Comment \\
\hline Pre-1850 & Vegetation clearance by Maori & \multirow{3}{*}{ First signs of erosion becoming apparent } \\
\hline $1880 s-1920$ & Vegetation clearance by early Europeans & \\
\hline $1920 \mathrm{~s}$ & Early geologists' warnings of erosion & \\
\hline 1938 & Big floods and regional landsliding & Early documentation of problem \\
\hline 1941 & $\begin{array}{l}1941 \text { the Soil Conservation and Rivers Control Act was } \\
\text { passed }\end{array}$ & $\begin{array}{l}\text { Catchment boards were given the task to manage and prevent soil } \\
\text { erosion on farmland }\end{array}$ \\
\hline 1944 & Poverty Bay Catchment Board formed & \multirow[t]{2}{*}{ First attempts to deal with the problem on farmland at a local scale } \\
\hline 1947 & Big Floods and regional landsliding & \\
\hline 1960 & First plantings by New Zealand Forest Service (NZFS) & First attempt at large-scale reforestation in this region \\
\hline 1963 & $\begin{array}{l}\text { Soil Conservation and Rivers Control Council appointed a } \\
\text { technical committee of inquiry. The committee reported } \\
\text { back in } 1967\end{array}$ & $\begin{array}{l}\text { First attempts to deal with the problem on farmland at a regional } \\
\text { scale }\end{array}$ \\
\hline 1967 and 1970 & $\begin{array}{l}\text { East Coast Project - report back 1967Formal publication } \\
1970\end{array}$ & Taylor Report \\
\hline Late 1970s & Reviews of East Coast Project & $\begin{array}{l}\text { 'Red Report' plus an Economic report (Ministry of Works and } \\
\text { Development) }\end{array}$ \\
\hline $1979-85$ & $\begin{array}{l}\text { Small-scale farm afforestation known as 'Protection- } \\
\text { Production Forestry Encouragement Grants' }\end{array}$ & NZFS grants for erosion control on small areas of marginal farmland \\
\hline 1987 & Demise of New Zealand Forest Service & Major restructuring led to foreign ownership of ex-State Forests \\
\hline 1988 & Cyclone Bola & $\begin{array}{l}\text { Largest landslide/flood in living memory. Return period > } 100 \text { years. } \\
\text { National disaster declared. }\end{array}$ \\
\hline 1988 & Parliamentary Commissioner for the Environment report & Inquiry into flood mitigation measures following Cyclone Bola \\
\hline 1988-1992 & East Coast Conservation Forestry Scheme & $\begin{array}{l}\text { Forerunner to the East Coast Forestry Project but restricted to two } \\
\text { southern catchments }\end{array}$ \\
\hline 1993 & East Coast Forestry Project & Region-wide scheme \\
\hline 1993 & Parliamentary Commissioner for the Environment review & Water and soil resource management on the East Coast \\
\hline 1994 & Parliamentary Commissioner for the Environment review & Sustainable land management and the East Coast Forestry Project \\
\hline 1998 & East Coast Forestry Project review & $\begin{array}{l}\text { Significant review by Bayfield and Meister (1998) resulted in changec } \\
\text { objectives }\end{array}$ \\
\hline $2000-2001$ & East Coast Forestry Project 2000 & New singular objective - space planted poles, reversion options \\
\hline 2002 & East Coast Forestry Project 2002 & \multirow{2}{*}{$\begin{array}{l}\text { Revised guidelines and widening of treatment options. Review by } \\
\text { Bayfield and Meister (2005) resulted in changed objectives, move } \\
\text { towards grant rather than tender, focus on gully planting, } \\
\text { introduction of covenants }\end{array}$} \\
\hline 2005 & East Coast Forestry Project review & \\
\hline 2005 & Discussion paper for the review of ECFP & MAF June 2005 , submissions \\
\hline 2006 & East Coast Forestry Project Grant Guidelines & $\begin{array}{l}\text { Implemented changes from } 2005 \text { review, moved from a tender to a } \\
\text { grant, introduced 50-year land covenant to protect plantings }\end{array}$ \\
\hline 2010 & Discussion paper on review of MAF afforestation schemes & \multirow[t]{2}{*}{ December 2010, submissions } \\
\hline 2010 & Other MAF schemes PFSI, AGS etc. & \\
\hline 2011 & Review of MAF Afforestation Schemes & \multirow[t]{2}{*}{ MAF Information Paper 2011/07 Review Panel } \\
\hline 2020 & Funding for ECFP due to cease & \\
\hline
\end{tabular}

introduced grass species. Such a drastic change in vegetation cover from forest to grazed pasture proved to be a powerful predisposing cause of accelerated erosion. Slope stability declined as the root systems of the indigenous forest began to decay. With the removal of the forest, interception by the forest canopy ceased. Soil moisture levels subsequently increased and soils remained wetter for longer and were thus more prone to mass wasting (Pearce et al., 1987). The onset of degradation of pastoral hill country occurred within a decade or two following deforestation (Hill, 1895; Henderson and Ongley, 1920) supported by observations of increased channel aggradation and flooding (Kennedy, 1912; Laing-Meason, 1914). 
Today, erosion (landsliding, earthflow, gullying) in the East Coast region of the North Island is unique. This region (Figure 1) comprises 7.8 per cent of the North Island in area yet contains 26 per cent of the land considered to be severely eroding (Eyles, 1985). Approximately 57 per cent of the East Coast region is severely erodible and the impacts from flooding, landsliding and sedimentation are considered greater than for other areas of New Zealand. For example, the three main rivers on the East Coast account for about one-third of New Zealand's total annual suspended sediment yield being generated from only 2.5 per cent of New Zealand's land area (Hicks et al., 2004).

Assessments of the region's long-term sediment budget indicate that gullies are the dominant sediment source in each of the major river systems in this region (Marden et al., 2008a). Sediment derived from sources including stream banks and cliffs (De Rose and Basher, 2011), slopewash from both pasture (Page et al., 2004, 2008) and forest cutover (and by storm-driven erosion processes associated with the forest post-harvest period (2-8 years after harvesting) (Marden et al., 2006, 2007) are, in the long term, several orders of magnitude less than that from shallow landslides (Reid and Page, 2002) and gullies (Marden et al., 2005, 2011; Marden, 2012). Estimated annual rates of denudation for hill country typical of the East Coast region are from $150 \mathrm{~m}^{3} \mathrm{~km}^{-2}$ to $500 \mathrm{~m}^{3} \mathrm{~km}^{-2}$ (Crozier et al., 1992).

In summary, uplift, weak geology, relief, susceptibility to rain storms, and vegetation clearance have all contributed to high rates of total erosion (denudation) giving this region the distinction of being one of the most erosion-prone regions of New Zealand and in the world (Williams, 1980).

\section{Results}

Policies and approaches

Southern Prealps Region of France

As outlined above, erosion problems appeared in the Southern Prealps of France during the Little Ice Age, due to the combination of climate change and poor agricultural practices (Neboit, 1991; Vallauri et al., 2002). The first written reports that pointed out the linkage between deforestation and erosion in the mountains dated back to the early 19th century (Dugied, 1819; Surell, 1841), but the French administration did not start to take erosion into consideration until the first strategic transport infrastructures were established in the mountains (see Mather et al. (1999) for an historical and socio-political account). The Code Forestier of 1827 provided the basis for developing how forests were to be managed, though made only modest provision for reforesting. The political decision to engage an ambitious programme of reforestation in the Alps was made in 1860, with the promulgation of the first law for the reforestation of mountains - the Restauration des terrains en Montagne (RTM) Act. This political process was clearly accelerated by the catastrophic flood of May-June 1856 in the Rhône River, which had a strong influence on policymakers (Bravard, 2002). This extreme flood had dramatic consequences, notably at Lyon, with several hundreds of houses destroyed and 18 persons killed. Two other laws were passed in 1864 and 1882 to improve and complete the legislative case for erosion control in the mountains. The erosion-control programme lasted 50 years, from the 1860 s to the First World War. Degraded lands were purchased by the State to implement reforestation and torrent-control engineering works. About 65000 ha were successfully reforested during this period (Blanchard, 1945). By the end of the 19th century, most of the degraded marly terrain in the Southern Alps in France had been afforested, primarily with Austrian black pine (Pinus nigra J.F. Arnold ssp, nigra) (Vallauri et al., 2002) in order to control erosion and torrential floods.

Between the two World wars, less money and fewer workers were available for restoration works. This period also coincided with the rural depopulation of the mountains and the strong spontaneous recovery of the forest cover (Taillefumier and Piégay, 2003) over thousands of hectares. Revegetation works dramatically decreased and attention was paid to the maintenance of existing works. The law of 1922 created the 'protection forests', preserving them from uncontrolled harvesting and degradation. In 1946, a National Forest Fund (FFN) was created to help establish new forests and manage the existing ones. But these incentives did not produce the expected results.

In the 50 years up to the present, changes in mountain land use led the Restauration des terrains en Montagne (RTM) service to adapt its services. Apart from maintaining existing engineering works, they were mainly devoted to regulating urban expansion and delineating risk zones, especially through the establishment of risk prevention plans (PPR). The latter are standard documents that determine risk areas and building authorizations. In these maps, red zones are 'no building' zones, blue zones are 'building zones under conditions' and white zones are 'building' zones. Since 2001, 'green zones' also exist, corresponding to forest zones with a function of hazard control. For these zones, obligations, prohibitions and recommendations for forest management are explained (harvesting, roads, etc.). The proposed management rules are not only applied to the public but also to private forests (Berger and Rey, 2004). While the RTM service continued maintaining torrent structures, forest management has been entrusted to the French National Forest Office (ONF), which is charged with their renewal and maintaining their role in hazard 
control. Several "best practice" handbooks have also been written (Gauquelin and Courbaud, 2006; Rey et al., 2009; Ladier et al., 2011).

\section{East Coast North Island Region of New Zealand}

Efforts to treat widespread erosion in New Zealand before the 1940s were largely local and piecemeal. Although the concepts that would later form the basis for 'protection forests' (e.g. Poole, 1960; Dorren et al., 2004) were generally understood (largely imported from Europe and elsewhere that had experienced similar issues), it was not until the Soil Conservation and Rivers Control Act of 1941 that the first national coordination (through regional catchment boards) and impetus to deal with both erosion and flooding problems were provided.

In the East Coast, the primary drivers for the observed large-scale erosion were clearance of the indigenous forest, its geological make-up and the severity of regional and local-scale storm events. In this region, policies to address the chronic erosion problem largely followed what was happening at the national level and a chronology of approaches is outlined in Table 1.

The first significant regional action was the intervention by the New Zealand Forest Service (NZFS) in 1960 to begin to reforest large tracts of eroding farmland in the headwaters of the main river systems with exotic plantations. With the devolution of the NZFS in 1987, impetus for treating erodible land largely ceased. This restructuring of the forest industry in New Zealand led to a massive downsizing of government involvement in the forestry sector (Aldwell and Roche, 1992; Roche, 1996). Through the late 1980s and early 1990s the harvesting rights to a large proportion of the forest assets developed by the State (but not the land) were sold to private largely offshore investors.

A severe storm in 1988 (Cyclone Bola) highlighted the need to continue with broad-scale treatment of land that had been severely damaged or was at risk of further erosion. New programmes, such as the East Coast Forestry Project (ECFP), a major government reforestation initiative unique to Gisborne District were implemented. The ECFP began in 1992 and heralded significant changes in land use from pastoral farming to closed-canopy Pinus radiata D. Don forestry on 'target' and 'eligible' land. Landholders, through a tender process, could apply for grants to plant trees on land where pastoral farming was no longer a sustainable option. 'Target' land was severely erodible, but other 'eligible' not-so-steep land could be included within the forest boundary, to make blocks of practical economic size. This resulted in some cases of whole farms being planted but 'good' farmland was often lost. When it was first established, the ECFP's primary goal was to encourage landowners to establish trees on erosion-prone areas of their farms. Secondary goals were regional development, new employment prospects and nature conservation. The project's initial target was to plant 200000 ha of commercial forest at an annual planting rate of 7000 ha on severely eroding and erosion-prone land in the East Coast. The programme is due to end in 2020 (Table 1).

However, fluctuations in the economics of forestry and farming have over the years significantly affected forest planting. Whenever forestry experienced a downturn, landholders tended to put off planting trees and continue with farming, and vice versa. In 1998, the government reviewed the ECFP, and subsequently amended the project's multiple aims to a single goal - with the expectation that secondary benefits would flow from this. The new single goal was to achieve sustainable land management on 60000 ha of the most severely eroding target land. The original focus, which concentrated only on planting commercial tree species, was also changed to include a wider choice of species. This included widespaced plantings of willows and poplars and also natural indigenous regeneration. In 2001 the project criteria were broadened to include 'alternative treatment' on land where other species at various planting densities would be able to halt erosion. Fencing to allow reversion to indigenous vegetation on erosion-prone land with scattered scrub became another possible option.

After a review of the ECFP (Bayfield and Meister, 2005), it was decided that uptake of grant money had been too erratic and slow, and that it was time for a 'carrot and stick' approach. This involved inserting a rule into the District Plan (a legal instrument) requiring landowners/managers of the most erosion prone land (described as Overlay $3 \mathrm{~A}$ ) to establish trees or shrubs at the appropriate density, and to maintain tree cover already present on such land, with the ECFP providing the subsidy in the form of a grant (tender). Landowners had from 2006 to 2011 to either establish the required vegetation or develop a works plan outlining the stages of planting to be completed by 2021 . This rule effectively meant that farmers were part-funded by government to treat eroding land on their properties. The area mapped in the District Plan as Overlay 3A the worst of the worst' was about 51000 ha of which about 12000 ha is still in need of treatment (Malcolm Penn, MPI pers. comm.). This land is also 'target' land under the ECFP. The key difference between the two approaches is that ECFP target land had a more regional focus and emphasised plantation establishment while for Overlay 3A consideration was at the individual property level, and included other treatment options such as traditional soil conservation planting with willow and poplar poles.

In the last decade, other central government schemes have promoted land rehabilitation across New Zealand the Permanent Forest Sink Initiative (PFSI), Afforestation 
Grants Scheme (AGS), and Hill Country Erosion Programme. Delivered through the Ministry of Agriculture and Forestry (MAF, now Ministry for Primary Industries), these schemes were largely driven by New Zealand's former commitment to the Kyoto Protocol to enhance carbon sequestration and increase the national area of Kyotocompliant forests (climate change initiatives), although complementing the efforts of the ECFP to treat erodible land. While all schemes are applicable to the East Coast region and have multiple purposes (carbon sequestration, biodiversity enhancement, land rehabilitation), the ECFP is targeted solely at this region with the primary purpose of reducing sediment generation.

\section{Bio-physical responses}

\section{Southern Prealps Region of France}

In the Southern French Prealps, 65000 ha have been planted with Austrian black pine (Figure 2) - 15000 ha in Haute-Provence, 10000 ha in Drôme and 4000 ha in Hautes-Alpes. These planted protection forests have effectively maintained their role of controlling erosion for more than 140 years but their advanced age is now beginning to cause additional problems. These old monoculture forests, with a dominant tree age of approximately 120 years have a structure that is regular and dense (more than 1500 stems $\mathrm{ha}^{-1}$ ). Tree heights vary from 12 to $27 \mathrm{~m}$ and the average radial growth is equal to $1.16 \mathrm{~mm} \mathrm{yr}^{-1}$. These stands are increasingly prone to large-scale catastrophic phenomena such as wind destruction, fires and parasitic attacks. The uncontrolled and short-term death of these 'first-generation' forests could lead to local reactivation of erosion (Rey and Berger, 2006). Moreover, mistletoe (Viscum album L.) has recently appeared on black pine and continues to propagate, accelerating deterioration (Vallauri et al., 2002).

While historically effective, the use of bioengineering works is currently limited in France but still widely used alongside "hard" structural measures in other European alpine countries such as Austria, Italy, and Switzerland (e.g. Evette et al., 2009). Reasons for the apparent decline in France are uncertain but could include: loss of knowledge about bioengineering techniques, difficulty in deciding which technique to use where, and a general lack of trust in the efficacy of vegetative methods compared to "hard" engineered control measures. While bioengineering, in particular the use of cuttings, is often the preference of managers of mountain lands as well as local communities, there is a general need to better understand the efficacy and the vulnerability of bioengineering works during floods.

The increase in vegetation cover in the last 150 years is closely coupled with a decrease in the sediment yield at the outlets of revegetated catchments. Field measurements in marly lands show that the fine sediment yield is 220 times less in the Brusquet catchment, which has an 87 per cent vegetation cover, compared with the Laval catchment which has only a 32 per vegetation cover (Mathys et al., 2003). In other basins, the reduction of coarse sediment yield has led to river incision (Liébault et al., 2005). In addition, in the Durance catchment, excessive fine sediment yield is still currently causing social (inundations), economic (silting of hydroelectric dams) and ecological damage (degradation of fish habitats).

In France, as well as in other areas in Europe and in countries with a Mediterranean climate, erosion management practices have resulted in two contrary situations. In some catchments, the reduced water discharges from hydropower dams are insufficient to transport all the suspended load which then accumulates in river channels, notably in areas of the active channel encroached by riparian vegetation. Habitats for fish reproduction may thus be damaged, flood risks may increase, and hydroelectric dams can fill with sediment. In contrast, other catchments suffer from a lack of bedload in the river, following intensive gravel mining in the 1970s and 1980s. As a consequence, river channels are incised which can then cause the undermining of bridge support structures and eventual collapse. Channel incision can also result in the lowering of groundwater tables, with important consequences for the ecology of riparian forests. As already stated, the vegetation cover is an important factor in the control of erosion and supply of sediment to rivers. Therefore, when there is an oversupply of sediment in river channels, erosion on slopes and riverbanks can be controlled through ecological restoration or rehabilitation operations, in particular using bioengineering techniques. Conversely where there is a deficit in sediment supply, erosion can be reactivated by removing vegetation on highly erodible slopes. The latter has been trialled at small-scale experimental sites to characterise the effect of vegetation removal on sediment production (Liébault et al., 2008; Pont et al., 2009). Results from this field experiment showed that for the same rainfall conditions, the sediment production of the deforested catchment is 3 times higher than for the undisturbed catchments (Bordeaux et al., 2010). The comparison of sediment responses observed before and after the deforestation revealed a 2.5 -fold increase of specific sediment yields that can be attributed to the effect of clear-cutting (Bordeaux et al., 2010). It is likely that this effect will decrease over time under the effect of spontaneous vegetation encroachment on deforested terrains.

\section{East Coast North Island Region of New Zealand}

Since reforestation began in the East Coast in the early 1960s, progress towards dealing with the erosion problem has been incremental as the various schemes outlined above 
have come and gone. In the East Coast region, there are 835 500 ha of erosion-prone hill country (90 per cent of region's area) (Marden, 2012) of which indigenous forest and scrubland make up about 220000 ha (26 per cent) and exotic forest about 170000 ha (20 per cent) (Eastland Wood Council, pers. comm.), the balance being pastoral farmland.

There is now about 25 per cent in reforested land (163 306 ha) (Table 2). However, only about one-half of this area was planted with government assistance and is on land that had been identified, at least at a regional scale, in need of blanket planting because it was severely eroding. The other half was planted by private forest investors (Table 2). Since the inception of the ECFP in 1992, ca. 39000 ha of hill country has been planted and ca. 9000 ha allowed to revert to native bush (Table 3). At 2005, the project had paid out about NZ\$28 million as grants. However, private investor forestry has slowed in the last decade as has non-subsidised farm-forestry woodlots undertaken by landowners.

The policies that have contributed to the treatment of erodible land have also had other social and economic impacts in the region. These are not elaborated on, but social and economic assessments have previously been made (e.g. Phillips and Marden, 2005; Fairweather et al., 2000). However, the value of the forest industry that has been built on the back of these land treatment forests is a significant contributor to the local and regional economy but at a national level, the contribution to the national forest area is relatively small (about 8 per cent) (Ministry of Agriculture and Forestry, 2011).

While there has been a significant amount of land 'treated' by various schemes there remains a level of resistance to either retiring the remaining erosionprone land from pastoral agriculture or to putting more trees into pastoral landscapes. Advocacy, education, planning rules, and time are all needed to bring about the changes necessary to reduce the level of erosion in this region.

Following decades of ongoing erosion as a result of the initial forest clearance on the East Coast, reforestation treatments were observed to begin to have effects

Table 2 Approximate reforested areas from all sources for East Coast Region as at end of 2011 planting season

\begin{tabular}{lr}
\hline Agent/project & Area (ha) \\
\hline New Zealand Forest Service (NZFS) & 36100 \\
East Cape Catchment Board & 2017 \\
NZFS protection/production grants & 1809 \\
East Coast Conservation Forestry Scheme & 13578 \\
East Coast Forestry Project & 38951 \\
Private (non-government-assisted at 2003) & 70851 \\
Total & 163306 \\
\hline
\end{tabular}

within about a decade of their establishment (Liebault et al., 2005; Marden et al., 2011) (Figure 3). Many of these, however, were at local scale, such as in headwater streams. Early observations indicated that many active slope processes slowed or ceased. These included a marked reduction in shallow landsliding (Phillips et al., 1990; Marden et al., 1992a; Marden and Rowan, 1993), substantially reduced rates of earthflow movement (Zhang et al., 1993; Marden et al., 2008a) (Figure 3), and cessation of gullying processes (Marden et al., 2011; Marden, 2012).

At the same time, it was also observed that small headwater streams began to incise into the thick deposits of sediment that had accumulated since initial forest clearance. In these areas, it was concluded that downcutting was in response to reduced sediment supply from slopes and perhaps to reduced stream flow as a result of increasing interception by the closing (or closed) canopy forest (Peacock and Turner, 2003; Peacock and Marden, 2004). However, even though sediment production from hillslopes reduced, changes in the rate of sediment accumulation in the main river channels has not translated to wholesale stream degradation across all catchments and headwaters (Liebault et al., 2005). A small amount of stream degradation was also observed after Cyclone Bola in 1988 (Banbury, 1996) suggesting that reforestation had been successful in facilitating the recovery on hillslopes.

While the hillslope and headwater channel responses were relatively dramatic, there has been a less discernible channel response downstream beyond the forests and on the flood plain of the major rivers like the Waipaoa (Kasai et al., 2005). Although inchannel capacity of the Waipaoa River has remained constant, flood capacity within the stopbanks has been reducing (Gomez et al., 1999) but it continues to be unclear what the flood plain responses to reforestation have been.

Sediment yields also showed declines following reforestation but these did not become apparent until much later (decades following establishment) (Marden et al., 1992b; Gomez et al., 2003). The principal reason is that many of the numerous gullies that were treated by reforestation continued to supply sediment until the trees reached canopy closure. However, there are still a number of large gully systems that are still to stabilise and they currently dominate the sediment supply to the Waipaoa River (Marden et al., 2008b; 2012).

In a similar manner, there were also noticeable ecological-water quality benefits from reforestation, again particularly observable in the headwaters. A pine plantation established on degraded pastoral hill country in soft rock terrain appeared, in time, to improve water quality and stream health towards conditions found in 
Table 3 Planting achievements since the East Coast Forestry Project began (Nick Pollock, MPI, pers. comm.)

\begin{tabular}{|c|c|c|c|c|c|}
\hline Year & $\begin{array}{l}\text { Planting } \\
\text { year }\end{array}$ & $\begin{array}{c}\text { ECFP } \\
\text { grant } \\
\text { (ha) }\end{array}$ & $\begin{array}{c}\text { Non- } \\
\text { qualifying } \\
\text { area }\end{array}$ & $\begin{array}{c}\text { Total area } \\
\text { planted } \\
\text { (ha) }\end{array}$ & $\begin{array}{c}\text { Informal } \\
\text { reserves } \\
\text { (ha) }\end{array}$ \\
\hline 1 & 1993 & 1911.1 & 1021.8 & 2932.9 & 753.7 \\
\hline 2 & 1994 & 2980.6 & 696.1 & 3676.7 & 387.9 \\
\hline 3 & 1995 & 2464.2 & 55.1 & 2519.3 & 224.7 \\
\hline 4 & 1996 & 4764.3 & 335.1 & 5099.4 & 1009.9 \\
\hline 5 & 1997 & 4266.1 & 456.2 & 4722.3 & 903.7 \\
\hline 6 & 1998 & 3504.8 & 168.9 & 3673.7 & 557.1 \\
\hline 7 & 1999 & 3724.9 & 117.0 & 3841.9 & 1004.2 \\
\hline 8 & 2000 & 2442.7 & 63.3 & 2506.0 & 797.7 \\
\hline 9 & 2001 & 931.7 & 23.7 & 955.4 & 204.4 \\
\hline 10 & 2002 & 2133.0 & 0 & 2133.0 & 1337.7 \\
\hline 11 & 2003 & 1102.0 & 0 & 1102.0 & Not assessed \\
\hline 12 & 2004 & 1254.4 & 0 & 1254.4 & Unknown \\
\hline 13 & 2005 & 578.8 & 0 & 578.8 & Unknown \\
\hline 14 & 2006 & 620.3 & 0 & 620.3 & Unknown \\
\hline 15 & 2007 & 376.4 & 0 & 376.4 & Unknown \\
\hline 16 & 2008 & 730.2 & 0 & 730.2 & Unknown \\
\hline 17 & 2009 & 898.0 & 0 & 898.0 & Unknown \\
\hline 18 & 2010 & 916.4 & 0 & 916.4 & Unknown \\
\hline 19 & 2011 & 3351.0 & 0 & 3351.0 & Unknown \\
\hline Total & & 38951.3 & 2937.2 & 41888.1 & ca. 9000 \\
\hline
\end{tabular}

Grant $=$ area established under ECFP project.

Non-qualifying area $=$ additional areas not paid for by the ECFP but established by the tenderer at their cost (additional benefit). Informal reserves = parcels of indigenous bush or standing scrub excluded by ECFP, i.e. not allowed to be clearfelled, are not covenanted or fenced and do not receive grants. streams draining native forest (Parkyn et al., 2006). The other major benefit was reduction of the amount of sediment being delivered to the coast (Hicks et al., 2004).

\section{Discussion}

Using the Southern Prealps region in France and the East Coast North Island region of New Zealand as 'study sites', past and current revegetation efforts were compared to address steepland degradation, and both physical and historical similarities and differences between them have been outlined in terms of problem recognition and policy and landscape responses (Table 4). Though defining success in terms of policy intervention may be debatable, it is clear that significant land use change has occurred in the East Coast region over 50 years and that this has had measurable effects on reducing hillslope erosion and the amount of sediment being transported within the region's rivers. Similar achievements are also demonstrable in France though the time frame is longer and the scale of interventions more widespread. In both countries, the impetus for reforestation of degraded lands follows Mather et al.'s (1999) crisis-response model: large floods seem to have been significant triggers for State intervention in reforesting degraded and erosion-prone land. While large floods seem to have been triggers for State interventions, once such events have not occurred for some time, usually several decades, there is often a swing back to nonintervention. Ericksen (1971) suggests that even in areas of frequent flooding, pressure for action is often shortlived pointing to both institutional and human memory being short and why interventions such as reforestation policies may only show moderate success. Further, this also highlights the mismatch between political/societal time-frames and geological/geomorphic time-frames. In the New Zealand case, the ECFP intended from its inception to be a 20 year programme to address some of these short-term social-political swings. In contrast, in France the RTM was essentially environmental in nature, geared

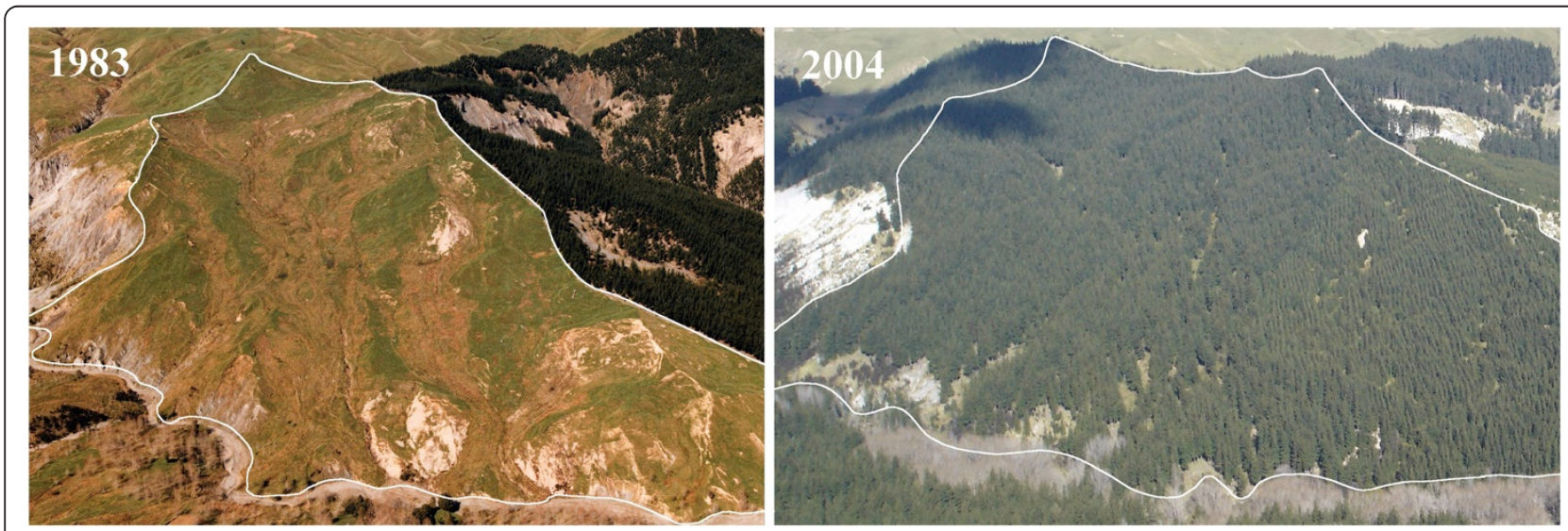

Figure 3 The 'Wether Run' earthflows in Mangatu Forest in 1983 and following planting in 2004 with Pinus radiata (photos: Marden, 2004). 
Table 4 Summary of similarities and differences between the two study areas

\begin{tabular}{|c|c|c|}
\hline Attribute/Action & East Coast New Zealand & Southern Prealps France \\
\hline Terrain & Moderately steep & Low elevation mountains \\
\hline Geology & Cretaceous and Tertiary rocks, mudstones, sandstones, argillites & Jurassic and Cretaceous sedimentary rocks, marls \\
\hline \multirow[t]{3}{*}{ Climate } & Rainfall 1000 - 2500 mm & Mountainous with Mediterranean influences \\
\hline & Susceptible to cyclones & Mean annual rainfall 850-1000 mm \\
\hline & & Convective storms in headwaters \\
\hline \multirow[t]{2}{*}{ Historical deforestation - when } & Some pre-1800's most late 1800's and early 1900's & Neolithic period \\
\hline & & $15^{\text {th }}$ and $19^{\text {th }}$ centuries human-induced erosion \\
\hline \multirow[t]{2}{*}{ Historical deforestation - why } & Some vegetation clearance by Maori pre-1850 & Climate change and agriculture expansion \\
\hline & Widespread vegetation clearance by early Europeans 1880's & Industrial demand for wood \\
\hline \multirow[t]{2}{*}{ Recognition of "problem" } & Early warnings 1920's & Early $19^{\text {th }}$ century \\
\hline & Big floods 1938-1947 & $\begin{array}{l}\text { Late } 19^{\text {th }} \text { century hillslope erosion, head water } \\
\text { channels aggrading }\end{array}$ \\
\hline \multirow[t]{4}{*}{ Policy intervention } & Soil Conservation and Rivers Control Act 1941 & $\begin{array}{l}\text { Reforestation in mountains } 1860 \text { - Restauration } \\
\text { des terrains en Montagne Act (RTM) }\end{array}$ \\
\hline & Catchment Board 1944 & Other laws to control erosion 1864, 1882 \\
\hline & Demise of New Zealand Forest Service 1987 & Erosion control programme lasted 50 years \\
\hline & East Coast Forestry Project 1993 & up to First World War \\
\hline \multirow[t]{4}{*}{ Revegetation } & New Zealand Forest Service plantings 1960's & Species used - Pinus ngira J.F.Arnold \\
\hline & Species used - Pinus radiata & Protection forests 120 - 140 year old trees \\
\hline & Protection/production forests & \\
\hline & 30 year old trees before harvesting & \\
\hline \multirow[t]{3}{*}{ Landscape response } & Observations of hillslope processes slowing 1980's - 1990's & Decrease in sediment yield \\
\hline & Headwater channel responses 1990's & River incision \\
\hline & Main channel responses not observed but constant & Reduced flows in some rivers \\
\hline \multirow[t]{2}{*}{ Channel interventions } & Raising stop banks & Dams \\
\hline & & Gravel extraction \\
\hline
\end{tabular}

to the restoration of degraded land, and with a time horizon of as many as 140 years (Mather et al. 1999).

Policies aimed at putting vegetation back into eroding steeplands have worked in both study areas giving confidence that reforestation is an effective treatment to deal with regional erosion in areas like the East Coast and the southern French Prealps. It is also now known how long it takes for these treatments to become effective in terms of surface and shallow landslide erosion, which is largely a function of when trees reach a closed canopy state (Marden, 2004, 2012; Marden et al., 2012). With other treatments such as spaced plantings and natural reversion, it appears that these require a longer time to become effective (see Phillips et al., 2008).

While the French example was aided by natural regeneration and rural depopulation, resistance to tree establishment (native, exotic, plantation, spaced planted, reversion) has continued to be an issue that both central and regional government agencies in New Zealand have struggled with. Regulatory agencies such as the Gisborne District Council were initially slow to respond to the need to reforest preferring traditional soil conservation approaches over blanket cover forests. However, in recent years there has been more pressure applied to landowners who have severely eroding land on their farms deemed to require treatment (e.g. Gisborne District Council Overlay 3A outlined in Herzig et al., 2011). In these situations, the landowners now have a statutory obligation to address the problem.

Even during the time of the NZFS (1960-1987), there was strong resistance by pastoral landowners to convert or plant parts of farms in trees. In the East Coast region that sentiment has largely continued to the present day with the uptake of grants (i.e. central-governmentfunded voluntary incentives (subsidies)) being erratic and relatively poor. There has not been a year where the ECFP has been over- subscribed. This may have been a function of the size of the incentive, the rules that were attached to the grant (i.e. covenants), or to a general 'anti-tree' sentiment. In some instances the grants paid to landowners for tree establishment have been negated 
when the young forests failed because stock had access, damaging the trees. Reasons why this may be an issue in New Zealand compared to France could be that New Zealand could be regarded as still being in a "pioneering" phase of its development with deforestation having occurred only a few generations ago while in France they have had a longer post- deforestation history and a longer period where revegetation efforts were either protected by law or were regarded by the community as providing a valuable service.

The influence of vegetation on a river's sediment production, especially in mountainous areas, is often difficult to evaluate. In France, situations of excessive sediment supply and sediment deficit sometimes coexist within a catchment, making land management decisions difficult. Also the scientific results from case study catchments are not always well transferred in New Zealand to inform management decisions.

In the long term on the East Coast, the expected reduction in sediment generation from the early reforestation of the most degraded hill slopes will continue to result in declining rates of bed load aggradation with potential off-site benefits such as reduced costs of bridge replacement and road repair; obviation of the need for expensive channel excavation, realignment and or stopbank construction; and a likely reduction in the incidence of flooding of low-lying, high-value farmland (Marden, 2012).

In France, managers of erosion-sensitive land are required to provide effective protection against erosion (Rey and Berger, 2006), which may be a combination of vegetation and bioengineering works. Rey et al. (2004) regard it as unnecessary to establish total vegetation cover in a catchment to stop sediment yield at its exit, when vegetation barriers are used to trap sediment. Current investigations require an interdisciplinary approach and are aimed at determining the minimum area to restore with bioengineering, especially in torrential gullies.

A similar approach is proposed for the reactivation of erosion in sediment-starved river basins. GIS-based mapping procedures were developed to identify sediment sources that could be reactivated to replenish bedload (Liébault et al., 2008). The criteria used to identify these sites include the lithology of the eroded terrains, proximity to the incised reach, and their connectivity to the target reach. Another example of this is the Magra River basin in Italy (Tuscany) where strategies were defined to promote sediment supply to incised river channels (Rinaldi et al., 2009). There, sub-catchments were classified according to the propensity of their sediment sources to deliver coarse sediment to river channels. This classification was used to define an integrated scheme for sediment transport restoration.
Results of investigations on the efficiency of vegetation and bioengineering works for gully erosion control are currently applied elsewhere to rehabilitate eroded lands. For example, it is possible to restore the vegetation cover on eroded gullies after forest fires, rockfalls or windstorms. It is also possible to decrease silting of reservoirs and ponds where erosion has increased the supply of fine sediment in river basins (Rey, 2009).

In New Zealand, while substantial areas of the East Coast have been reforested or 'treated, most of this region is still susceptible to erosion. While generally the 'worst of the worst' land has had some treatment, there are still substantial areas of the region that are susceptible to shallow landslide erosion during extended wet periods or moderate to large storm events. Debates are ongoing about land use and land sustainability, flooding, and the implications for delivery of sediment off hillslopes into streams, rivers, and to the coast. Long term, and with climate change assessments indicating increasing likelihood of more storminess, though overall drier conditions (Tait, 2011), there is still a pressing need to establish more trees on the landscapes of the East Coast region, particularly on steeper slopes.

In terms of policy, in a 2010 review of reforestation schemes the New Zealand Ministry of Agriculture and Forestry (2011) concluded 'there was no reason (specific to erosion prevention) why the East Coast should be singled out for special treatment, with its own scheme' as erosion can be as problematic in other regions. However, the Review's terms of reference did not allow major changes to the ECFP and all four afforestation/reforestation schemes, with modifications, were supported for continuation. As no new government money is likely to be forthcoming due to other current priorities (rebuild of earthquake-damaged Christchurch), the recommended separation of payments for carbon from other services provided by forestry (erosion control, water quality, biodiversity, etc.) within a single nationwide programme charged with the task of erosion prevention is unlikely to proceed in the present economic climate (global downturn and government departments operating under tight fiscal constraints).

Recent changes to carbon prices and potential changes to New Zealand's emissions trading scheme are resulting in less investment for forestry. Coupled with economic returns from forestry as a whole being highly varied and linked to external exchange rates, increasing high costs for managing and harvesting forests on steeplands, increasing anti-forestry sentiments arising from harvesting and wood residue issues it is likely that investment in erosion-related forestry is not going to improve.

The long-term future of forested lands in New Zealand is also coming under scrutiny as forests that were established by the NZFS in the first wave of land 
treatment continue to be harvested. An emerging issue relates to the harvesting of timber from these forests, whereby rivers that were muddy and sediment-laden in floods over the last 50-100 years are now, in similar floods, transporting increasing amounts of woody debris. This debris arises from headwater forests undergoing harvesting, from moribund soil conservation and river control plantings of poplars and willows, and occasionally from areas of indigenous vegetation. This woody debris is accumulating on flood plains and coastal beaches. Increasing concern about such off-site impacts appears to be growing from a public that has enjoyed the erosion-protection benefits from forests for many decades.

In addition to wood residue in rivers and on beaches arising from harvesting operations and/or storms on harvested forests, concerns are also being expressed about the visual appearance of clear-cut forests, increased export of logs from a port that might not be able to handle the volume coming on stream, and more logging trucks in residential areas and their impact on road pavements. With urbanization, the New Zealand public is increasingly becoming disconnected from the primary sector (agriculture and forestry) who are finding it difficult to meet local societal expectations as well as international requirements for accreditation systems for their products.

A further issue is that the products of past erosion have resulted in elevated stream beds, extensive valley fills, and accreting floodplains creating a vast amount of material for potential removal by stream processes. Unfortunately on the East Coast unlike in France, much of this material is of poor quality and cannot be used as roading aggregate.

New Zealand, unlike many other countries, has continued to rely on reforestation (a soft measure) to control erosion rather than use a mix of soft and hard (engineered) approaches that are common in developed countries to control erosion. Population density and infrastructure in many of these countries requires a higher level of protection than rural land in New Zealand and is the primary reason why hard engineered approaches in combination with vegetation are favoured. However, in both France and New Zealand, structural soil bioengineering measures for controlling erosion and sediment generation are virtually absent from managed landscapes, though they do appear to be making a comeback in France (Rey 2009). Traditional hard engineering is still common in France but less so in New Zealand.

\section{Conclusions}

Landscape responses to large-scale erosion and subsequent reforestation have been similar between France and New Zealand though major reforestation occurred in France more than a century before that in New Zealand. Geomorphic responses in the form of reduced slope erosion and subsequent channel responses are well documented in both countries (Mathys et al., 2003; Peacock and Marden, 2004; Rey et al., 2004; Piégay et al., 2004; Liébault et al., 2005; Pont et al., 2009; Marden, 2012) and the effect that vegetation cover has on hillslope erosion processes and the strong coupling between hillslopes and channels are also clearly demonstrated. However, attempts to control sediment production in headwater regions reinforces the view that conditions controlling the evolution of channel response (through time and space) to a change in sediment supply are complex (Liébault et al., 2005; Pont et al., 2009). While there is a consistent sequence of responses in channels and on hillslopes to reforestation efforts and the direction of changes may be predictable or anticipated, the magnitude and timing of those responses are not.

The key lesson for future management and policy development arising from these studies is that erosioncontrol efforts that are aimed at producing basin-scale impacts will require targeting of areas where the proposed land use change or intervention will have the most beneficial influence on reducing sediment supply to river channels (e.g. Pont et al., 2009; Rey, 2009; Osterkamp et al., 2012). As Pont et al. (2009) conclude, "a comprehensive view of the situation at the catchment level will promote necessary solidarity between all partners to reach a common agreement and to approve a sediment management plan".

In the East Coast region in New Zealand, there has been a move towards a more targeted approach that builds on the foundation of the earlier blanket reforestation of headwaters by the NZFS. It has become apparent, however, that without central government funding of these schemes, it is likely that treatment rates would have fallen off dramatically in the last few decades with a consequent increase in more eroded land and soil loss.

Over time, the policy effort in New Zealand has seen a movement from 'protection' to 'production' with a dependency on market forces to achieve what had originally been a publicly-funded protection effort. This has resulted in patchy investment and potentially costly forest production. Long term there is a potential for different policy approaches with a return to more 'protection' approaches, particularly if natural 'disasters' (floods, landslides, etc.) continue to occur on a regular basis. This may result in more natural land reversion or a shift to alternative species that can be grown over longer rotations than radiata pine. However, it is anticipated that little will be achieved without central government intervention and funding.

In the Southern Prealps in France, to avoid sediment transport at catchment outlets, low-cost rehabilitation 
actions can be employed such as using bioengineering techniques within small gullies to trap and retain eroded materials before they reach the catchment outlet. Based on results of current research carried out in the French Southern Prealps, a specific strategy for such interventions is proposed, along with rules for use of bioengineering structures and methods for determining priority actions. This strategy for fine sediment retention using bioengineering works is currently being applied on eroded marly catchments in the French Southern Alps, in a mountainous Mediterranean climate (Rey, 2009).

In summary, the link between vegetation and reduced erosion has been demonstrated for the study areas as well as for many parts of the globe (e.g., Collins et al., 2004). Many nations have long recognised this link and have, at various times in their history, instigated interventionist polices to deal with erosion and its consequences, particularly in river channels (e.g., Evette et al., 2009: Marston 2010). However, many of these interventions are often short-lived as the memory of the event that triggered the initial response fades with time and economies grapple with competing demands for internal resources. The result is that for many countries, erosion continues to occur at alarming rates, reducing the future options on many classes of land. For most countries, it also often takes a series of large natural disasters producing a scale of damage beyond that of an individual landowner or a local government to deal with to provide the necessary stimulus to address the problem. It's also clear that while individual countries had their own ways of dealing with these problems, 'solutions' were often shared as can be seen in the similarity of many control techniques in our study catchments in France and New Zealand.

\section{Competing interests}

There are no competing interests.

\begin{abstract}
Authors' contributions
This paper arose from discussions held in France when the first author (CP) visited Grenoble in 2009. The concept of the paper was the first author's and the outline was developed collaboratively with all co-authors. FR and FL drafted the French components, CP and MM the New Zealand components. $\mathrm{CP}$ pulled the final manuscript together. All authors read and approved the final manuscript.
\end{abstract}

\footnotetext{
Acknowledgements

We thank Malcolm Penn and Nick Pollock (Ministry for Primary Industries, Gisborne, NZ) for updated information on the East Coast Forestry Project. Ian Lynn reviewed the paper and Christine Bezar edited it. This research was supported in part by funding from the former Ministry of Science and Innovation (contract no. CO4X0806 'Protecting and Enhancing the Environment through Forestry') to Scion/Future Forest Research. Reported results from the land use change effects on sediment responses in the Southern French Alps were supported by ZABR (Zone Atelier Bassin du Rhône) and ORE (Observatoire de Recherche en Environnement) Draix-Bléone.
}

\section{Author details}

${ }^{1}$ Landcare Research, PO Box 40, Lincoln 7640, New Zealand. 'Irstea Grenoble, UR EMGR and ETNA, 2 rue de la papeterie, 38402, Saint Martin d'Hères Cedex, France. ${ }^{3}$ Landcare Research, PO Box 445, Gisborne 4010, New Zealand.

Received: 5 February 2013 Accepted: 1 August 2013

Published: 02 Oct 2013

\section{References}

Aldwell, P, \& Roche, M. (1992). Dismantling the New Zealand Forest Service. In R LeHeron, E Pawson, \& S Britton (Eds.), Changing Places in New Zealand: a Geography of Restructuring (pp. 118-119). Christchurch, NZ: New Zealand Geographical Society.

Banbury, K. (1996). Changes in sediment storage in Te Weraroa Stream, East Coast, New Zealand, 1948-1996. Auckland, NZ: MSC thesis University of Auckland.

Bayfield, MA, \& Meister, AD. (1998). East Coast Forestry Project review. Wellington NZ: Report to Ministry of Agriculture and Forestry.

Bayfield, MA, \& Meister, AD. (2005). East Coast Forestry Project review. Wellington NZ: Report to Ministry of Agriculture and Forestry.

Berger, F, \& Rey, F. (2004). Mountain protection forests against natural hazards and risks: new French developments by integrating forests in risk zoning. Natural Hazards, 33, 395-404.

Blanchard, R. (1945). Les Préalpes françaises du Sud. Paris: B. Arthaud.

Bordeaux, C, Liébault, F, Landon, N, Justin, C, \& Cave, B. (2010). Forêt et recharge sédimentaire de rivières torrentielles : possibilités d'actions sur la base des expérimentations Drôme et Ouvèze. Rhône-Alpes Lyon: Technical report, Office National des Forêts, Direction Technique.

Bravard, JP. (2000). Le comportement hydromorphologique des cours d'eau au petit âge glaciaire dans les Alpes françaises et sur leur piedmont. In Bulletin du Groupe Francophone Humidimétrie et traNsferts en milieux poreux (GFHN) (46) (pp. 105-110).

Bravard, JP. (2002). Le 'traitement' des versants dans le département de la Drôme, des inondations de 1840 à la loi du 27 juillet 1860. Annales des Ponts et Chaussées, 103, 37-43.

Bravard, JP, \& Peiry, JL. (1993). La disparition du tressage fluvial dans les Alpes françaises sous l'effet de l'aménagement des cours d'eau (19-20ème siècles). Zeitschrift für Geomorphologie, Supplement, 88, 67-79.

Brochier, JL, Mandier, P, Argant, J, \& Petiot, R. (1991). Le cône détritique de la Drôme: une contribution à la connaissance de l'Holocène du sud-est de la France. Quaternaire, 2, 83-99.

Buoncristiani, JF, Petit, C, Campy, M, Bossuet, G, \& Richard, H. (2002). Quantification de l'ablation d'un bassin versant marno-calcaire alpin durant le Petit Age Glaciaire par l'étude d'un système lacustre (cas du lac du 'Claps' de Luc-en-Diois, Drôme, France). Geodinamica Acta, 15, 103-111.

Cohen, M, \& Rey, F. (2005). Vegetation dynamics and water erosion on marls in the French Southern Alps. Géomorphologie : Relief, Processus, Environnement, $1,31-44$.

Crozier, MJ, Gage, M, Pettinga, JR, Selby, MJ, \& Wasson, RJ. (1992). The stability of hillslopes. In MJ Soons \& MJ Selby (Eds.), Landforms of New Zealand (pp. 64-90). Auckland, NZ: Longman Paul.

Cumberland, KB. (1947). Soil Erosion in New Zealand. Wellington, NZ: Whitcombe and Tombs.

De Beaulieu, JL. (1977). Contribution pollenanalytique à l'histoire tardiglaciaire et holocène de la vegetation des Alpes méridionales françaises. France: Unpublished PhD thesis, Université Aix-Marseille.

De Rose, RC, \& Basher, LR. (2011). Measurement of river bank and cliff erosion from sequential LIDAR and historical aerial photography. Geomorphology, $126,132-147$

Debelmas, J. (1983). Alpes du Dauphiné Guides Géologiques Régionaux. Paris: Masson.

Demontzey, P. (1880). Studien uber die Arbeiten der Wiederbewaldung und Berasung der Gebirge. Vienna: Carl Gerhold's Sohn.

Dorren, LKA, Berger, F, Imeson, AC, Maier, B, \& Rey, F. (2004). Integrity, stability and management of protection forests in the European Alps. Forest Ecology and Management, 195, 165-176.

Dugied, MPH. (1819). Projet de boisement des Basses-Alpes. Paris: Imprimerie Royale.

Ericksen, NJ. (1971). Human adjustment to floods in New Zealand. New Zealand Geographer, 27, 105-129. doi:10.1111/j.1745-7939.1971.tb00657.x. 
Evette, A, Labonne, S, Rey, F, Liebault, F, Jancke, O, \& Girel, J. (2009). History of bioengineering techniques for erosion control in rivers in Western Europe. Environmental Management, 43(6), 972-984.

Eyles, GO. (1985). The New Zealand Land Resource Inventory Erosion Classification, Ministry of Works and Development, Soil Conservation Centre, Aokautere (Water and Soil Miscellaneous Publication, 85, pp. 1-61). Wellington: Ministry of Works.

Fairweather, JR, Mayell, PJ, \& Swaffield, SR. (2000). Forestry and agriculture on the New Zealand East Coast: socio-economic characteristics associated with land use change. Research Report 247, Agribusiness Economics Research Unit. Canterbury, NZ: Lincoln University.

Gage, M, \& Black, RD. (1979). Slope stability and geological investigations at Mangatu State Forest. New Zealand: Forest Service Forest Research Institute Technical Paper. 66.

Gauquelin, X, \& Courbaud, B. (2006). Guide des sylvicultures de montagne (Alpes du Nord françaises). ONF-Cemagref-CRPF.

Gisborne District Council. (2012). One in a hundred year storm. In Conservation Quorum 67 (Autumn) (pp. 1-3). Gisborne: Gisborne District Council.

Glade, T. (1998). Establishing the frequency and magnitude of landslidetriggering rainstorm events in New Zealand. Environmental Geology, $35,160-174$.

Gomez, B, Eden, DE, Hicks, DM, Trustrum, NA, Peacock, DH, \& Wilmshurst, JM. (1999). Contribution of floodplain sequestration to the sediment budget of the Waipaoa River. In SB Mariott \& J Alexander (Eds.), Floodplains: Interdisciplinary Approaches (pp. 377-395). New Zealand: Geological Society of London Special Publication 163.

Gomez, B, Banbury, K, Marden, M, Trustrum, NA, Peacock, D, \& Hosking, P. (2003). Gully erosion and sediment production, Te Weraroa Stream, New Zealand. Water Resources Research, 39, 1187-1195.

Henderson, J, \& Ongley, M. (1920). The geology of the Gisborne and Whatatutu subdivisions, Raukumara Division. Bulletin 21 (New Series). Wellington, NZ: Geological Survey Branch, Department of Mines, Government Printer.

Herzig, A, Dymond, JR, \& Marden, M. (2011). A gully-complex model for assessing gully stabilisation strategies. Geomorphology, 133(1-2), 23-33.

Hicks, DL. (1995). A way to estimate the frequency of rainfall-induced mass movements (note). Journal of Hydrology (NZ), 33, 59-67.

Hicks, DM, Gomez, B, \& Trustrum, NA. (2004). Event suspended sediment characteristics and the generation of hyperpycnal plumes at river mouths: East Coast continental margin, North Island, New Zealand. Journal of Geology, $112,471-485$.

Hill, H. (1895). Denudation as factor of geological time. Transactions and Proceedings of the New Zealand Institute, 28, 666-680.

Kasai, M, Brierly, GJ, Page, MJ, Marutani, T, \& Trustrum, NA. (2005). Impacts of land use change on patterns of sediment flux in Weraamaia catchment, New Zealand. Catena, 64, 27-60. doi:10.1016/j.catena.2005.06.014.

Kelliher, FM, Marden, M, Watson, AJ, \& Arulchelvam, IM. (1995). Estimating the risk of landsliding using historical extreme river flood data (note). Journal of Hydrology (NZ), 33, 123-129.

Kennedy, CD. (1912). Flood prevention report: Poverty Bay River District. Poverty Bay Herald, 5. 12 October.

Kittredge, J. (1948). Forest Influences. New York, NY: McGraw-Hill.

Ladier, J, Rey, F, \& Dreyfus, P. (2011). Guide des sylvicultures de montagne (Alpes du Sud françaises). Paris: ONF-Irstea-INRA.

Laing-Meason, G. (1914). Prevention of floods: the Waipaoa River trouble. Poverty Bay River Board report on flood prevention. Gisborne Times, 11. 17 July.

Liébault, F, \& Piégay, H. (2002). Causes of 20th century channel narrowing in mountain and piedmont rivers of Southeastern France. Earth Surface Processes and Landforms, 27, 425-444.

Liebault, F, Gomez, B, Page, M, Marden, M, Peacock, D, Richard, D, \& Trotter, CM. (2005). Land-use change, sediment production and channel response in upland regions. River Research and Applications, 21, 739-756.

Liébault, F, Piégay, H, Frey, P, \& Landon, N. (2008). Tributaries and the management of main-stem geomorphology. In SP Rice, A Roy, \& BL Rhoads (Eds.), River Confluences, Tributaries and the Fluvial Network (pp. 243-270). Chichester, UK: John Wiley.

Marden, M. (2004). Future-proofing erosion-prone hill country against soil degradation and loss during large storm events: have past lessons been heeded? New Zealand Journal of Forestry, 49(3), 11-16.

Marden, M. (2012). Effectiveness of reforestation in erosion mitigation and implications for future sediment yields, East Coast catchments, New Zealand: A review. New Zealand Geographer, 68, 24-35.
Marden, M, \& Rowan, D. (1993). Protective value of vegetation on tertiary terrain before and during Cyclone Bola, East Coast, North Island, New Zealand. New Zealand Journal of Forestry Science, 23, 255-263.

Marden, M, Phillips, CJ, Jackson, RJ, Zhang, XB, \& Ekanayake, JC. (1992a). A decade of earthflow research and inter related studies in the North Island of New Zealand. In Proceedings of International Symposium on Erosion, Debris Flows, and Environment in Mountain Regions (pp. 263-271). Chengdu, China: IAHS Publication 209

Marden, M, Phillips, C, \& Rowan, D. (1992b). Declining soil loss with increasing age of plantation forests in the Uawa Catchment, East Coast Region, North Island, New Zealand. In P Henriques (Ed.), Sustainable Land Management. Napier, Hawke's Bay, New Zealand: Proceedings of the International Conference on Sustainable Land Management. 17-23 November 1991.

Marden, M, Arnold, G, Gomez, B, \& Rowan, D. (2005). Pre- and post-reforestation gully development in Mangatu Forest, East Coast, North Island, New Zealand. River Research and Applications, 21, 757-771.

Marden, M, Rowan, D, \& Phillips, C. (2006). Sediment sources and delivery following plantation harvesting in a weathered volcanic terrain, Coromandel Peninsula, North Island, New Zealand. Australian Journal of Soil Research, 44, 219-232.

Marden, M, Rowe, L, \& Rowan, D. (2007). Slopewash erosion following plantation harvesting in pumice terrain and its contribution to stream sedimentation, Pokairoa catchment, North Island, New Zealand. Journal of Hydrology (NZ), 46, 73-90.

Marden, M, Betts, HD, Arnold, G, \& Hambling, R. (2008a). Gully erosion and sediment load: Waipaoa, Waiapu and Uawa Rivers, eastern North Island, New Zealand. In J Schmidt, T Cochrane, C Phillips, S Elliott, T Davies, \& L Basher (Eds.), Sediment Dynamics in Changing Environments, Christchurch, New Zealand, December 2008 (pp. 339-350). Wallingford, UK: International Association of Hydrological Sciences. Publication 325.

Marden, M, Rowan, D, \& Phillips, C. (2008b). Recurrent displacement of a forested earthflow and implications for forest management, East Coast Region, New Zealand. In J Schmidt, T Cochrane, C Phillips, S Elliott, T Davies, \& L Basher (Eds.), Sediment Dynamics in Changing Environments, Christchurch, New Zealand, December 2008 (pp. 491-501). Wallingford, UK: International Association of Hydrological Sciences. Publication 325.

Marden, M, Herzig, A, \& Arnold, G. (2011). Gully degradation, stabilisation and effectiveness of reforestation in reducing gully-derived sediment, East Coast region, North Island. Journal of Hydrology, 50, 19-36.

Marden, M, Arnold, G, Seymour, A, \& Hambling, R. (2012). History and distribution of steepland gullies in response to land use change, East Coast Region, North Island, New Zealand. Geomorphology, 153, 81-90.

Marston, RA. (2010). Geomorphology and vegetation on hillslopes: interactions, dependencies, and feedback loops. Geomorphology, 116(3-4), 206-217.

Mather, AS, Fairburn, J, \& Needle, CL. (1999). The course and drivers of the forest transition: the case of France. Journal of Rural Studies, 15, 65-90.

Mathys, N, Brochot, S, Meunier, M, \& Richard, D. (2003). Erosion quantification in the small marly experimental catchments of Draix (Alpes de Haute Provence, France). Calibration of the ETC. rainfall-runoff-erosion model. Catena, 50, 527-548.

Mazengarb, C, \& Speden, IG. (2000). Geology of the Raukumara area. Institute of Geological and Nuclear Sciences 1:250 000 geological map 6. 1 sheet +60 p. Lower Hutt, NZ: Institute of Geological and Nuclear Sciences. Comp.

McKelvey, P. (1992). The development of the concept of steepland protection forestry in New Zealand (New Zealand Journal of Forestry, May, pp. 20-24). New Zealand Institute of Forestry.

Ministry of Agriculture and Forestry. (2011). Review of MAF afforestation schemes: Permanent Forest Sink Initiative, Afforestation Grant Scheme, East Coast Forestry Project, Sustainable Land Management (Hill Country Erosion) Programme. Wellington, NZ: MAF Information Paper No. 2011/07.

Neboit, R. (1991). L'homme et l'érosion, l'érosion des sols dans le monde. Faculté des Lettres et Sciences Humaines de I'Université. Clermont-Ferrand, France: Blaise-Pascal.

O'Loughlin, CL, \& Owens, IF. (1987). Our dynamic environment. In PG Holland \& WB Johnston (Eds.), Southern Approaches: Geography in New Zealand (pp. 59-90). Christchurch: New Zealand Geographical Society.

Osterkamp, WR, Hupp, CR, \& Stoffel, M. (2012). The interactions between vegetation and erosion: new directions for research at the interface of ecology and geomorphology. Earth Surface Processes and Landforms, $37(1), 23-36$.

Page, MJ, Trustrum, NA, Brackley, HL, \& Baisden, WT. (2004). Erosion-related soil carbon fluxes in a pastoral steepland catchment, New Zealand. Agriculture, Ecosystems and Environment, 103(3), 561-579. 
Page, MJ, Marden, M, Kasai, M, Gomez, B, Peacock, D, Betts, H, Parkner, T, Marutani, T, \& Trustrum, N. (2008). Changes in basin-scale sediment supply and transfer in a rapidly transformed New Zealand landscape. In $\mathrm{H}$ Habersack, H Piegay, \& M Rinaldi (Eds.), Gravel-Bed Rivers VI: from Process to Understanding to River Restoration (pp. 337-358). Amsterdam: Developments in Earth Science Processes 11, Elsevier.

Parkyn, SM, Davies-Colley, R, Scarsbrook, MR, Halliday, NJ, Nagels, JW, Marden, M, \& Rowan, D. (2006). Pine afforestation and stream health: a comparison of land-use in two soft rock catchments East cape New Zealand. New Zealand Natural Sciences, 31, 113-135.

Peacock, DH, \& Marden, M. (2004). Bed level changes in the Raparapaririki, Mangapoi, and Mangawhariki Streams, Ruatoria (pp. 1-19). : Gisborne District Council Engineering \& Works Technical Report 2004/01(EWTR 2004/01). Gisborne District Council.

Peacock, DH, \& Turner, WJ. (2003). Waipaoa River flood control scheme-proposed review of scheme 3B (pp. 1-XX-155). : Gisborne District Council Report GDC 2003/410. Gisborne District Council.

Pearce, AJ, O'Loughlin, CL, Jackson, RJ, \& Zhang, XB. (1987). Reforestation: on-site effects on hydrology and erosion, eastern Raukumara Range, New Zealand. In Forest hydrology and watershed management, proceedings of the Vancouver symposium, August 1987 (Publication 167, pp. 489-497). Wallingford, UK: International Association of Hydrological Sciences.

Phillips, CJ, \& Marden, M. (2005). Reforestation schemes to manage regional landslide risk. In T Glade, M Anderson, \& MJ Crozier (Eds.), Landslide Hazard and Risk, (pp. 517-547). John Wiley.

Phillips, CJ, Marden, M, \& Pearce, A. (1990). Effectiveness of reforestation in prevention and control of landsliding during large cyclonic storms. In Proceedings XIX World IUFRO Congress, Volumes 1-6, August 5-11, 1990 (pp. 340-349). Montreal, Canada.

Phillips, CJ, Marden, M, Douglas, G, Mclvor, I, \& Ekanayake, J. (2008). Decision support for sustainable land management: effectiveness of wide-spaced trees. Lincoln, NZ: Landcare Research. Contract Report LC0708/126.

Piégay, H, Walling, DE, Landon, N, He, Q, Liébault, F, \& Petiot, R. (2004). Contemporary changes in sediment yield in an alpine mountain basin due to afforestation (the upper Drôme in France). Catena, 55, 183-212.

Poirel, A. (2009). Mesures des transports solides en suspension dans la Durance sur 150 ans (1857-2007) : liaisons avec les opérations de restauration écologique intervenues à l'échelle du bassin versant et de la rivière (pp. 85-98). Ingénieries EAT, special issue «Écologie de la restauration et ingénierie écologique : enjeux, convergences, applications ».

Pont, D, Piégay, H, Farinetti, A, Allain, S, Landon, N, Liébault, F, Dumont, B, \& Richard-Mazet, A. (2009). Conceptual framework and interdisciplinary approach for the sustainable management of gravel-bed rivers: the case of the Drôme River basin (S.E. France). Aquatic Sciences, 71, 356-370. doi:10.1007/s00027-009-9201-7.

Poole, AL. (1960). Protection forests in New Zealand, and a Poverty Bay example. New Zealand Geographer, 16, 115-130.

Reid, LM, \& Page, MJ. (2002). Magnitude and frequency of landsliding in a large New Zealand catchment. Geomorphology, 49, 71-88.

Rey, F. (2009). A strategy for fine sediment retention with bioengineering works in eroded marly catchments in a mountainous Mediterranean climate (Southern Alps, France). Land Degradation and Development, 20, 210-216.

Rey, F, \& Berger, F. (2006). Management of Austrian black pine on marly lands for sustainable protection against erosion (Southern Alps, France). New Forests, 31, 535-543.

Rey, F, Ballais, JL, Marre, A, \& Rovéra, G. (2004). Role of vegetation in protection against surface hydric erosion. Comptes Rendus Géoscience, 336, 991-998.

Rey, F, Ladier, J, Hurand, A, Berger, F, Calès, G, \& Simon-Teissier, S. (2009). Forêts de protection contre les aléas naturels - diagnostics et stratégies. QUAE.

Rinaldi, M, Simoncini, C, \& Piégay, H. (2009). Scientific design strategy for promoting sustainable sediment management: the case of the Magra River (Central-Northern Italy). River Research and Applications, 25, 607-625.

Roche, M. (1996). Forestry. In R Le Heron \& E Pawson (Eds.), Changing Places: New Zealand in the Nineties (pp. 160-168). Auckland, NZ: Longman Paul.

Schiechtl, HM, \& Stern, R. (1996). Ground Bioengineering Techniques for Slope Protection and Erosion Control. London: Blackwell Science.

Surell, A. (1841). Etude sur les Torrents des Hautes-Alpes. Paris: Dunod.

Taillefumier, F, \& Piégay, H. (2003). Contemporary land use changes in prealpine Mediterranean mountains: a multivariate GIS-based approach applied to two municipalities in the Southern French Prealps. Catena, 51, 267-296.
Tait, A. (2011). Climate change projections for New Zealand - a literature review. Lincoln, NZ: Landcare Research. NIWA Client Report WLG2011-48 for.

Vallauri, D, Aronson, J, \& Barbero, M. (2002). An analysis of forest restoration 120 years after reforestation on badlands in the southwestern Alps. Restoration Ecology, 10, 16-26.

Wellman, HW. (1962). Holocene of the North Island of New Zealand: a coastal reconnaissance. Transactions of the Royal Society of New Zealand Geology, 1, 29-99.

Williams, P. (1980). From forest to suburb: the hydrological impact of man in New Zealand. In AG Anderson (Ed.), The Land Our Future (pp. 103-124). Auckland, NZ: Longman Paul.

Wilmshurst, JM. (1997). The impact of human settlement on vegetation and soil stability in Hawke's Bay, New Zealand. New Zealand Journal of Botany, $35,97-111$.

Wilson, K, Litchfield, N, Berryman, K, \& Little, T. (2007). Distribution, age, and uplift patterns of Pleistocene marine terraces of the northern Raukumara Peninsula, North Island, New Zealand. New Zealand Journal of Geology and Geophysics, 50, 181-191.

Zhang, X, Phillips, CJ, \& Marden, M. (1993). A comparison of earthflow movement rates on forested and grassed slopes, Raukumara Peninsula, North Island, New Zealand. Geomorphology, 6, 175-187.

\subsection{6/1179-5395-43-14}

Cite this article as: Phillips et al:: Revegetation of steeplands in France and New Zealand: geomorphic and policy responses. New Zealand Journal of Forestry Science 2013, 43:14

\section{Submit your manuscript to a SpringerOpen ${ }^{\circ}$ journal and benefit from:}

- Convenient online submission

- Rigorous peer review

- Immediate publication on acceptance

- Open access: articles freely available online

- High visibility within the field

- Retaining the copyright to your article

Submit your next manuscript at $>$ springeropen.com 